\title{
ARCHAEOLOGY INTRODUCTION
}

Colin Renfrew

McDonald Institute for Archaeological Research, University of Cambridge. Email: acr10@cam.ac.uk.

The radiocarbon revolution may be seen in retrospect as the most decisive development in the archaeology of the 20th century. It is a pleasure, therefore, to have the opportunity of congratulating Radiocarbon on its jubilee celebration, and on the significant role that it has played in establishing a level of excellence in publication, against which the advances in that revolution could be measured. I well remember, as an undergraduate in Cambridge starting to read archaeology in 1960, how each new issue of Radiocarbon would be scrutinized for new dates bearing upon European prehistory. Glyn Daniel, then editor of Antiquity, would often begin a lecture with the announcement of some improbably early date for a Neolithic monument in Brittany or in Britain. It was clear that archaeology was being transformed, but not yet evident what the nature of the transformation would be.

Over the next decade or so, chronological structures that seemed secure and well-established were beginning to crumble while others remained unassailed. This led some archaeologists, understandably enough, to question whether the method was reliable. One distinguished professor in England pronounced that an early date for a particular Neolithic context was "archaeologically unacceptable," although he later recanted and came to accept the emerging pattern. In Germany, Professor Vladimir Milojčić became an outspoken skeptic, regularly denouncing the entire approach. I remember too my amazement when Glyn Daniel put into my hands an unpublished article by Hans Suess, giving for the first time a calibration curve based on ${ }^{14} \mathrm{C}$ determinations of dendrochronologically dated samples from the Californian bristlecone pine. This made samples that already appeared unexpectedly early to come out yet earlier! Professor Milojčić was scathing, and viewed such "calibration" as the ultimate demonstration of unreliability. But these were the foundations of the second radiocarbon revolution.

Today, the general reliability of the method is very widely accepted, but controversies remain. Some of these are noted in the papers that follow, which together review the impact of ${ }^{14} \mathrm{C}$ dating upon the archaeological world. The reception of the method in the Old World is well covered here by $\mathrm{Y}$ Kuzmin, and in the New World by R E Taylor. Their contributions are further discussed below.

Two papers here report progress on specific problem areas. The contribution by S Svyatko and colleagues reports on determinations of samples taken from skeletons from later prehistoric sites in Southern Siberia. It exemplifies well how absolute chronology of large regions, hitherto difficult to establish, is now becoming known. Comparable data are available for the southern Urals (Hanks et al. 2007). Gradually, the steppes of central Eurasia, that vast tract of land between the Balkans and China, are being explored archaeologically and chronologically. The second paper, by J van der Plicht and colleagues, seeks to clarify the conflict between the so-called "high" and "low" chronologies in Iron Age Israel and in archaeologically related areas. It makes use of the more sophisticated statistical data handling methods involving Bayesian analysis, advocated in the paper by A Bayliss, and hailed there as the "third radiocarbon revolution."

The interesting aspect for us here is that these papers are confronting the interpretive limits of the radiocarbon method. The fluctuations in the calibration curve at certain times imply that a single precise ${ }^{14} \mathrm{C}$ determination can validly represent 2 or even 3 different calendar dates. A single sample, even if analyzed repeatedly and with precision, cannot determine which interpretation is correct.

(C) 2009 by the Arizona Board of Regents on behalf of the University of Arizona Celebrating 50 Years of Radiocarbon

RADIOCARBON, Vol 51, Nr 1, 2009, p 121-122 
The problem was confronted many years ago by Hans Suess with his "wiggle matching" approach, using samples from successive time points in a wood sample studied dendrochronologically (Suess 1970; see Clark and Renfrew 1972). The Bayesian approach does not require that the relative ages of the successive samples be explicitly known in such a way, but simply that their sequence is well secured stratigraphically, as Bayliss outlines. But sophisticated analysis of this kind does not automatically resolve all problems, as the continuing failure to establish a generally acceptable date for the Late Bronze Age eruption of Thera in the Aegean indicates. The literature on that topic is now extensive (see Wiener 2003, 2007; Balter 2006), but ${ }^{14} \mathrm{C}$ specialists and Egyptologists are still locked in debate over an apparent difference of at least a century in the chronologies of the east Mediterranean at this time. For the chronological aficionado, the continuing failure conclusively to resolve the controversy over the dating of the Thera eruption represents an intriguing drama.

Finally, the paper here by E Boaretto rightly stresses the importance of good archaeological context for the samples selected for analysis, indicating that organic material accompanying layers of phytoliths, and organic material included in plasters and mortars, can yield datable material from clear stratigraphic contexts.

These papers testify to how much has been achieved over these 50 years. The reviews by Kuzmin and Taylor review the position well. Yet even they do not quite express what has been achieved, when viewed on a global scale. Sixty years ago, it was in generally not possible to date archaeological finds with precision unless these could be related to one of the historical calendars, whether Egyptian, or Chinese or indeed Maya. Vast parts of the globe lacked any secure chronology. Dating was nowhere possible before about $3000 \mathrm{BC}$. Now a secure chronology is available everywhere, so long as organic materials are available for dating. And of course other radiometric methods are also available to take the chronology back much earlier than the limits of ${ }^{14} \mathrm{C}$ dating, beyond 50,000 $\mathrm{yr}$ ago.

The implications are vast. The problem of diffusion versus independent invention (or "convergence" in biological terms) simply could not be addressed without a secure chronology. That chronology is everywhere becoming available, with limits of precision discussed here in the context of Bayesian analysis. It is a remarkable achievement, brought about by the joint efforts of many scientists. And Radiocarbon has done a great service in so authoritatively reporting their work.

\section{REFERENCES}

Balter M. 2006. New carbon dates support revised history of ancient Mediterranean. Science 312(5773): 508-9.

Clark RM, Renfrew C. 1972. A statistical approach to the calibration of floating tree-ring chronologies using radiocarbon dates. Archaeometry 14(1):5-19.

Hanks BK, Epimakhov AV, Renfrew AC. 2007. Towards a refined chronology for the Bronze Age of the southern Urals, Russia. Antiquity 81(312):353-67.

Suess HE. 1970. Calibrated radiocarbon dates. In: Suess HE, Strahm C. The neolithic of Auvernier, Switzerland. Antiquity 44(174):91-9.
Wiener MH. 2003. Time out: the current impasse in Bronze Age archaeological dating. In: Foster KP, and Laffineur R, editors. METRON, Measuring the Aegean Bronze Age (Aegaeum 24). Proceedings of the 9th International Aegean Conference, 18-21 April 2002. New Haven: Yale University. p 363-99.

Wiener MH. 2007. Times change: the current state of the debate in Old World chronology. In: Bietak M, Czerny $\mathrm{E}$, editors. The Synchronisation of Civilisations in the Eastern Mediterranean in the Second Millennium BC. Proceedings of the SCIEM 2000 Conference, Vienna, 28 May-1 June 2003. Vienna: Osterreichischen Akademie der Wissenschaften. p 25-47. 